\title{
IMPLEMENTATION OF INNOVATIVE PEDAGOGICAL TECHNOLOGIES I N THE CONTROL OF PHYSICAL EDUCATION OF STUDENTS OF SPECIAL MEDICAL GROUPS
}

\author{
L. Tsjovh, V. Koryahin, O. Blavt
}

Lviv Polytechnic National University, Ukraine

corresponding author-Blavt O.: oksanablavt@ukr.net

The relevance of the study is due to the objective need to increase the effectiveness of physical education of students in special medical groups during their training in higher education institutions. A promising direction for solving this problem is the development and practical implementation of new, highly effective control technologies. The purpose of the research: to identify conceptual approaches, the main tasks and mechanisms of the implementation of innovative pedagogical technology for controlling the physical education of students of special medical groups. Material and methods. The basis of the research is the use of a complex of general scientific theoretical methods: analysis, systematization, generalization, theoretical modeling. Results. The basic preconditions and bases of development and introduction of innovative technologies for control of physical education as the process of modernization of the existing control system are analyzed. Formulated conceptual approaches in this process, taking into account the specifics of the contingent of special medical groups. The task is substantiated, the structural components of the mechanism of implementation of innovative control technology are presented and analyzed. In the development of innovative technology, all cycles of diagnostics and management are integrated - from gathering information about the current state of the organism of students to the formation of managerial decisions. The theory of the regulation of cybernetic systems, the main elements of which are programming, screening, correction, is based on the innovative technology of controlling the course of physical education of students. The criterion for the effectiveness of the proposed provisions is the final analysis of the dynamics of the parameters of the psychophysical state of students of special medical groups in the process of their physical education. Conclusions. Integration of innovative technologies, through qualitative changes in the control of physical education of students of special medical groups, leads to an increase in the effectiveness of this process, before quantitative and qualitatively new results. The structure of technology presented in the work allows developing integrated algorithms of activity of subjects of realization of innovations, in order to ensure effective implementation of control of physical education of students of special medical groups, and, thus, increase of efficiency of this process in general.

Key words: physical education, student, special medical group, innovation, technology, efficiency.

\section{Introduction}

Social transformations in the context of globalization changes that accompany the process of reforming education in Ukraine, lead to the emergence and development of educational innovations as a powerful resource for the modernization and development of the education system as a whole. Nowadays, the very innovations are the basic factor in the creation of a new system of physical education in higher education institutions [7; 12]. doi:

Цьовх Л., Корягін В., Блавт О. Впровадження інноваційних педагогічних технологій у контролі фізичної освіти студентів спеціальних медичних груп

Анотація. Актуальність дослідження обумовлена об'єктивною необхідністю підвищення ефективності фізичного виховання студентів у спеціальних медичних групах у термін їхнього навчання у закладах вищої освіти. Перспективним напрямом вирішення даної проблематики $\epsilon$ розробка та практична реалізація нових високоефективних технологій контролю. Мета дослідження: виявити концептуальні підходи, основні завдання та механізми реалізації інноваційної педагогічної технології контролю фізичного виховання студентів спеціальних медичних груп. Матеріал і методи. В основу дослідження покладено використання комплексу загальнонаукових теоретичних методів: аналіз, систематизацію, узагальнення, теоретичне моделювання. Результати. Проаналізовано базові передумови та основи розробки та упровадження інноваційних технологій у контроль фізичного виховання, як процесу модернізації існуючої системи контролю. Сформульовано концептуальні підходи у цьому процесі з огляду на особливості контингенту спеціальних медичних груп. Обґрунтовано завдання, представлено й проаналізовано структурні складові механізму реалізації інноваційної технології контролю. У розробці інноваційної технології інтегровано усі цикли діагностики та управління - від збору інформації про поточний стан організму студентів до формування управлінських рішень. В основу інноваційної технології контролю ходу фізичного виховання студентів покладено теорія регулювання кібернетичних систем, основними елементами якої $\epsilon$ програмування, звірення, корекція. Критерієм ефективності запропонованих положень слугує підсумковий аналіз динаміки параметрів психофізичного стану студентів спеціальних медичних груп у процесі їхнього фізичного виховання. Висновки. Інтеграція інноваційних технологій, через якісні зміни у системі контролю фізичного виховання студентів спеціальних медичних груп, призводять до підвищення ефективності цього процесу, до здобуття кількісно і якісно нових результатів. Представлена у роботі структура технології дозволяє розробляти інтегровані алгоритми діяльності суб'єктів реалізації інновацій задля забезпечення ефективної реалізації контролю фізичного виховання студентів спеціальних медичних груп, а, відтак підвищення ефективності цього процесу загалом.

Ключові слова: фізичне виховання, студент, спеціальна медична група інновація, технологія, ефективність.

Innovative processes in education lead to the emergence of new approaches to the organization of the process of physical education of a leading character, which outline the perspective direction of the development of this system [21]. The problem of nationwide weight at present is the quality of higher education, which is equated with the quality of training of able-bodied professionals. The latter is provided by their proper state of health, which is the main driver of progress in all spheres of society and the state [4]. 
The problem of improving the health of young people can not be considered beyond the context of physical education, which today is ineffective in ensuring the psychophysical readiness of graduates of higher education to productive activities [1]. Within the framework of this problem, at the present stage, the issue of the effectiveness of physical education of students who, for the state of health, is directed at classes in special medical groups becomes of special significance.

Most scholars of the industry share those or other views on the ways of effective implementation of the targeted guidance of the physical education of students with a disability in the state of health, which requires an effective system of control $[4 ; 8 ; 11 ; 14 ; 15]$. According to the Resolution of the Cabinet of Ministers of Ukraine «On the List of Directions for the Training of Specialists in Higher Educational Institutions for the Educational Qualification Level of Baccalaureate» [16], the introduction of national standards in the education system is aimed at improving the quality of student preparation, in particular, on the basis of streamlining the system control. It is considered that one of the promising directions of increasing the efficiency of physical education in special medical groups is the development and practical implementation of new highly effective control technologies $[4 ; 11 ; 14]$. The latter is also due to the fact that the reform of the educational system involves a rethinking of the purpose and outcome of physical education and the corresponding modernization of content [5].

However, despite the considerable interest of scholars and practitioners in controlling matters in physical education, this problem is one of the least studied in pedagogical science. Specialists of the industry $[4 ; 20]$ focus on the peculiarity of control in the physical education of students with disabilities in health. At the same time, there is a contradiction between the rapid innovation development, the request and the need to update the content of control procedures implemented in its modernization, and the lack of integration of modern innovative technologies in this process $[5 ; 12 ; 21]$. The necessity of introducing innovations, fundamentally new approaches to the development of the theory of controlling the achievements of students in their physical education and the methods of their practical implementation in special medical groups that would correspond to the modern scientific ideas due to the reorganization of education in Ukraine, actualizes the problem of finding the introduction of innovative pedagogical technologies into the control system that are able to provide an effective solution to the problems of physical education of students with disabilities in health.

\section{Material and methods}

The purpose of the research is to identify conceptual approaches, the main tasks and mechanisms for the implementation of innovative pedagogical technology for controlling the physical education of students of special medical groups.

This research is theoretical qualitative research. The type of this research is descriptive modeling research. To achieve the assigned tasks the following research methods were used: general scientific methods of theoretical level: analysis and synthesis, systematization and generalization of research results in the ascertaining and the formative stages of experiment, theoretical modeling. The analysis in our study envisaged the dismemberment of control in the physical education of special medical groups in its components. Thus, they carried out a description of the parties, features, properties of this process, established their relationship in order to comprehensively study them. The synthesis envisaged the unification of the previously selected parts, sides, attributes, properties, control relationships in the physical education of special medical groups into a single whole. Generalization of the fixation of general features and control properties in the physical education of the special medical groups implemented the transition from unit to special and general, from less general to more general. The theoretical modeling is used to reproduce the model in accordance with the tasks of studying the essential properties of control implementation in the physical education of the special medical groups, its structures, relationships and relations between its elements [16; 18; 20].

\section{Results}

In UNESCO documents, pedagogical technologies are considered as a systematic method for the creation, application and definition of the entire teaching and learning process, taking into account technical and human resources and their interaction, which aims to optimize forms of education [20]. On the basis of generalization of information on this concept $[1 ; 2 ; 6 ; 10]$, it was found out that, on the one hand, pedagogical technologies a set of methods and means of processing, presentation, change and presentation of educational information, on the other - is a science of ways to influence the learning process using necessary means. We are joining the idea [4; 20] that the search for new innovative technologies is a process of modernizing the existing system of physical education. Consideration of the essential features of innovative pedagogical technologies requires the elaboration of the key concept of «innovation». "Innovation» means updating, changing, entering a new one [12]. In pedagogical interpretation, it involves innovations 
to improve the course and results of the educational process [7]. In the future, our research is aimed at realizing the idea that innovation modernization is necessary for the reorganization of the current state of control in the physical education of students at special medical groups and requires the search for new means to achieve its objectives. So, we distinguish the directions of implementation of the outlined conclusion. Therefore, innovations from the standpoint and in the context of our research, on the one hand - ideas, approaches, methods, technologies that have not been used up so far [20], on the other hand - a complex of elements or separate elements of the control process, with progressive undertakings, in relation to the formation of innovations in the system of physical education, which provides its modernization in the course of changes $[4 ; 20]$. The main direction of such a strategy is to create a pre-emptive monitoring system that will significantly improve the quality of the control procedures and the results obtained.

At the first stage of the formation of pedagogical innovations the conformity of innovations with the requirements to innovations is established. The first requirement is an idea. In our study, the innovation process in the control involves changes based on its modernization, in order to improve the quality of physical education of students in general. As a complex activity, it is associated with the creation of new, more sophisticated control mechanisms [4]. Technologization of the process of implementing innovations involves building a technology structure, which is determined directly on the basis of the essence of innovation as a process and its laws [12]. At present, in the practice of scientific research in this direction, there is no consensus on the technology to control the dynamics of the required indicators in the process of physical education. Let's consider only some useful, in our opinion, directions of structural and technological modernization of the control system.

It is believed [3] that the best results in controlling the parameters that indicate the quality of physical education can be achieved using for these purposes methods of mathematical modeling and modern means of information processing. That is why the concept of optimal management of the process of physical education of special medical group students can be realized provided the most complete and accurate information about the current state of psychophysical readiness of everyone. It is also the basis for the development of an integral assessment in the overall control system.

The constant search for new, more advanced forms and methods for controlling and assessing the students' psychophysical status aims, first of all, to improve the diagnosis of the current condition. On this basis, it is supposed to determine the ways of its further improvement.
Solving this problem will allow more purposefully planning the conduct of training work, which is the basis for building the entire system of management of physical education of students. We see this in the development of innovative technology that integrates all stages of diagnosis and management - from gathering information about the current state to the formation of managerial decisions.

At the same time, when constructing innovative technology, it is necessary to take into account the fact that the psychophysical state of students is a complex dynamic system with a large number of infrastructural connections [15]. The success of the existence of such systems under the influence of internal and external factors is based on stable qualitative and quantitative relationships (correlation), which were formed in the process of physical education. The basis for building an innovative technology for controlling the psychophysical state of students was the following tasks:

- improvement of the organization of control over the partial preservation of the current content;

- qualitative reorganization of the content of test control;

- optimization of the methodology of evaluation.

- prompt and timely provision of accurate, complete information on the results and quality of the implementation of physical education plans at special medical group;

- providing effective control feedback in the process of physical education;

- organization of meaningful purposeful influence of control during physical education.

The structure of innovative control technology implies the following:

1. Determination of the list of basic psychophysical qualities, depending on the illness of the students (for each specific group of diseases separately).

2. Determine the list of tests that are appropriate to use as a measurement tool.

3. Normative base of the indicators included in the technology.

4. Levels of interconnections between them, calculated on the basis of correlation interactions.

A prerequisite for the construction of technology is that it should have in its composition a relatively small number of tests [5]. In accordance with the fundamental provisions of the test theory [3], the main factor in ensuring the effectiveness of the test control in physical education is the authenticity of the applied techniques. All tests must meet its requirements: have a proper coefficient of validity and reliability, and the form of distribution of indicators must comply with the Gauss law.

The theory of N. A. Bernstein is based on the innovative technology of controlling the course of physical 
education of students on the regulation of cybernetic systems, the main elements of which are programming, screening, correction [20]. Thus, the assessment of certain parameters that demonstrate the effectiveness of pedagogical influences during the physical education of each particular student is to reconcile his individual characteristics obtained during the testing, with the norms, and the definition of differences in the level of individual indicators of normative characteristics. Such characteristics are in themselves a reflection of the qualitative and quantitative deviations of certain parameters from the norm. As a result, the obtained values of deviations can be considered as directions of possible correction of programs of physical education. It is these they are the basic basis for choosing the method of further training taking into account the individual characteristics of the health of each particular student. With the help of corrections during classes, the influence on qualitative changes in the structure of physical education is carried out. The latter is largely based on identifying signs that are lagging behind in development, but at the same time necessary to eliminate existing disabilities in the health of students. In this aspect, it is also important to take into account the gender characteristics and age-related changes that occur in the student's body during the training period in the higher education institutions. The mechanism of the implementation of innovative technology as an integral system must be determined by the unity of all its structural components, and the flexibility and reactivity of this system, necessary for timely adaptation to dynamic challenges, must be ensured by timely correction of pedagogical influences in the course of physical education of students. All components of the technology must function in a proper, focused on the end result, consistent unity [12].

Innovative technology for controlling the physical education of students should make it possible to determine its effectiveness. The criterion for the effectiveness of the proposed provisions is the final analysis of the dynamics of the parameters of the psychophysical state students of special medical groups in the process of their physical education. In general, the use of control technology will be more effective, the more it will focus on the individual dynamics of the parameters studied, rather than compliance with control standards. That is, according to the principles of individually oriented physical education.

\section{Discussion}

We fully support the scientific approaches of specialists engaged in finding ways to increase the effectiveness of physical education university students, as the main factor in their healthcare. In this context, we are joining the idea that the efficiency of this process can be greatly enhanced by adjusting the control system $[1 ; 4-6 ; 10 ; 11]$. There is a certain number of evidence that control in physical education is a determining factor, which limits the state of physical education of students as a whole. Unlike previous studies, we have conducted an investigation into the students who, for health reasons, are directed to classes in special medical groups $[3 ; 19 ; 20]$. Currently, the search for a mechanism for managing the effectiveness of the process of physical education students of special medical groups on the basis of adjusting control procedures remains fragmentary, inadequate and unreasonable. For the first time the research on optimization of control in the physical education students of special medical groups has been conducted in the context of innovative modern technologies. We support scientific approaches $[7 ; 12 ; 17$; $20 ; 21]$ that the strategic goal of the policy of innovative development of the system of physical education should be the creation of a favorable innovation environment that would ensure the introduction of scientific ideas and developments into the elements of this system in order to ensure its effectiveness.

The above data confirms and extends the results of the researches $[1 ; 7 ; 13]$ received concerning the problem of introduction of the newest technologies in the educational process of higher education. Taking into account existing researches $[4 ; 9 ; 11 ; 12]$, which prove the efficiency of using innovations in the process of physical education, the basic approaches and directions of integration of innovative technologies into the system of control of physical education of students of special medical groups are presented. The obtained results supplement the information on the control of the physical education of students of higher education institutions $[1 ; 4 ; 8 ; 15]$, and deepen the information on this process in relation to students of special medical groups.

\section{Conclusions}

The reform of education in Ukraine takes place in conditions of modernization processes in all branches of knowledge. In this context, innovative vectors for the development of physical education of students, as a means of preparing them for productive professional activity, are important. In modern conditions, only the transition to innovative development ensures the effectiveness of educational processes.

Integration of innovative technologies, through qualitative changes in the system of control of physical education of students of special medical groups, leads to an increase in the efficiency of this process, before quantitative and qualitatively new results in general. The reorganization principles of test control, which provide for its qualitative innovative modernization in order 
to ensure the tolerance of pedagogical influences in the physical education of special medical groups, are presented in the work. It is substantiated that, taking into account the totality of regulatory capabilities and the molding control potential, new positions and directions of scientific research of innovative approaches should be directed, firstly, to the fundamental rearrangement of control system technology, and secondly, to modernize this process through the use of innovations for its intensification.

The structure of technology presented in the work allows developing integrated algorithms of activity of

References

1. Ayers SF. (2004). High School Students' Physical Education Conceptual Knowledge. Research Quarterly for Exercise and Sport, 75(3): 272287. DOI: 10.1080/02701367.2004. 10609160.

2. Baghurst T., \& Mwavita M. (2014). Evaluation, rationale, and perceptions regarding fitness testing in physical education teacher education programs. The Global Journal of Health and Physical Education Pedagogy, 3: 348-364.

3. Bassett DR. (2000). Validity and reliability issues in objective monitoring of physical activity. Research Quarterly for Exercise and Sport, 71: 30-36.

4. Blavt O. (2016). System of control in physical education of students of special medical groups. Lviv Polytechnic Publishing House.

5. Di Tore P.A., Schiavo R., \& D’isanto T. (2016). Physical education, motor control and motor learning: theoretical paradigms and teaching practices from kindergarten to high school. Journal of Physical Education and Sport, 16(4): 1293-1297. DOI:10.7752/ jpes.2016.04205

6. Grabowski H. (2000). Co koniecznie trzeba wiedzieć o wychowaniu fizycznym. Kraków : Oficyna Wydawnicza «Impuls».

7. Gurtova TV., Korol OS., Nesgoda SP., \& Stetsiak OB. (2019). Physical culture as an object of innovations in higher education institutions: a modern approach. Scientific Journal of the National Pedagogical University named after. MP Drahomanov. Series 15: Scientific and pedagogical problems of physical culture (physical culture and sports), 2(108): 33-36.

8. Humphrey N., Lendrum A., Barlow A., Wigelsworth M., \& Squires G. (2013). Achievement for All: Improving psychosocial outcomes for students with special educational needs and disabilities. Research in Developmental Disabilities, 34(4): 1210-1225. DOI:10.1016/j. ridd.2012.12.008.

9. ledynak G., Galamandjuk L., Kyselytsia O., Balatska L., Nakonechnyi I., Mazur V. (2017). Physiological characteristics of pubertal schoolchildren with chronic diseases. Journal of Physical Education and Sport. 17(4): 2462-2466. doi:10.7752/jpes.2017.04275

10. Keating XD., \& Silverman S. (2009). Determinants of teacher implementation of youth fitness tests in school-basedphysical education programs. Physical Education \& Sport Pedagogy, 14(2): 209-225. DOI:10.1080/17408980801974945. subjects of realization of innovations, in order to ensure effective implementation of control of physical education students of special medical groups, and, thus, increase of efficiency of this process in general.

Consequently, the conducted scientific analysis allowed to reveal new reserves for increasing the effectiveness of physical education of students of IDUs, which have a deviation in the state of health, and outlines the prospects for achieving this through the modernization of all structural components of this process.

Conflict of interest. The authors state that there is no conflict of interest.

11. Koryahin V., Blavt O., Bakhmat N., Guska M., Ludovyk T., Prozar M., Bodnar A., Kravets S., \& Bezgrebelnaya E. (2019). Differentiated correction of attention abilities of students with chronic diseases during physical education. Journal of Physical Education and Sport, 19(2): 293-298. DOI:10.7752/jpes.2019.s2044.

12. Lyosota TI. \& Levytska OM. (2017). Innovative technologies in the system of physical education of students. Young Scientist, 3.1(43.1): 202-205.

13. Metzler M. (2011). Instructional Models in Physical Education. 3 edition. Routledge.

14. Macleod G., \& Cebula KR. (2009). Experiences of disabled students in initial teacher education. Cambridge Journal of Education, 39(4): 457-472. DOI:10.1080/03057640903352465.

15. Overton H., Wrench A., \& Garrett R. (2016). Pedagogies for inclusion of junior primary students with disabilities in physical education. Physical Education and Sport Pedagogy, 22(4), 414-426. DOI:10.1080/174089 89.2016.1176134.

16. Physical education of students / Ed. VM. Koryahin (2018). Lviv Polytechnic Publishing House.

17. Schislovsky SV. (2015). Some indicators of physical state of the high school students on the stage of implementation of contents of the physical culture program. Journal of Education, Health and Sport, 5(7): 631-640.

18. Shiyan, B. M, ledynak, G. A., Petryshyn, Y. V. (2012), Naukovi doslidzhennya u fizychnomu vykhovanni ta sporti [Scientific research in physical education and sports], Oiyum, Kamyanets-Podilsky, Ukraine.

19. Silverman S., Keating XD., \& Phillips SR. (2008). A lasting impression: A pedagogical perspective on youth fitness testing. Measurement in Physical Education and Exercise Science, 12: 146-166. DOI: 10.1080/10913670802216122.

20. Stolyarov VI. (2015). Theory and methodology of modern physical education: state of development and author's concept: monograph. K.: Olympic literature.

21. Tymoshenko OV., \& Demin ZhG. (2016). How to modernize the national system of physical education? Modern Educational Dimension. Education, 15: 6-10. 